\title{
メッシュサイズ変更法を導入した SA/GA ハイブリッド最適化手法*
}

\author{
坂本 裕一郎 ${ }^{* 1}$, 盆子原 康博 ${ }^{* 2}$, 近藤 孝広 ${ }^{* 3}$, 阿部 憲治 ${ }^{* 4}$, 谷口 智之 ${ }^{* 4}$ \\ SA/GA Hybrid Optimization Method Using a Procedure of Mesh Size Change \\ Yuichiro SAKAMOTO*1, Yasuhiro BONKOBARA, Takahiro KONDOU, \\ Kenji ABE and Tomoyuki TANIGUCHI \\ ${ }^{* 1}$ Graduate School of Engineering, Department of Intelligent Machinery and Systems, \\ Faculty of Engineering, Kyushu University \\ 744 Motooka, Nishi-ku, Fukuoka-shi, Fukuoka, 819-0395 Japan
}

\begin{abstract}
SA/GA hybrid optimization method developed in a previous study is improved in order to achieve high computational performance. In the previous study, design variable vector elements are placed on the lattice point in order not to spawn too many similar solutions. Although this approach restrict the number of combination patterns related to design variable vector, if the interval of lattice points is narrow, members of search individuals are more likely to fall into local solutions because narrow interval makes huge combination pattern. In the proposed method using a procedure of mesh size change, in order to improve the computational performance, mesh size which means interval of the lattice points is set larger at the beginning of the optimization. Then, interval is narrowed as calculation is more progressed. The validity of the present method is confirmed by the calculation examples. In addition, assistance method which determine when mesh size should be changed using convergence ratio is applied to the proposed method in order to achieve more high computational performance. The calculation example shows the validity of this additional method.
\end{abstract}

Key Words : Optimal Design, Framed Structure, Genetic Algorithm, Multi-Objective Optimization, Hybrid Optimization Method, Simulated Annealing, Mesh Size Change

\section{1. 緒言}

近年 , パソコンなどの高性能で安価な計算機ハードウェアが普及したことを背景にして，産業界では CAE 技術 の導入が急速に進んでいる．とくに，製品開発の現場では，大幅な性能向上や低コスト化に向けて CAEによる最 適設計を実施する事例が増えており, 開発者の要求に対応した最適解を効率的に求めるために多種多樣な最適設 計手法か開発されている. 光の中でも，自然界における事象を模擬した発見的手法 ${ }^{(1)} に$ 分類される手法か数多くあ り，代表的なものとして遺伝的アルゴリズム ${ }^{(2)}$ や擬似焼き鈍し法 ${ }^{(3)}$ が挙げられる . 両者とも最適解の候補（以下， これを探索個体と呼ぶ）の生成と評価を試行的に繰り返し行う計算アルゴリズムによって最適解を探索する手法 であり，最適解が大域的に存在し得る多目的最適化問題にも適用することが可能である．しかしながら，多目的 最適化問題では目的関数が複杂住な多峰性を有している場合が多く，探索個体が局所解に滞りがちである.このた め, パレート最適フロントを十分に精度良く求めるためには, 局所解を適切に回避しながら解空間の探索を実行 できるように計算アルゴリズムを工夫することが重要である .

このような観点から，著者らは 2 次元骨組構造物の位相・形状同時多目的最適化問題を対象としたハイブリッ

* 原稿受付 2011 年 9 月 19 日

*1 正員, 九州大学大学院工学府（T819-0395 福岡県福岡市西区元岡 744）

*2 正員, 九州大学大学院工学研究院

*3 正員, フェロー, 九州大学大学院工学研究院

*4 学生員, 九州大学大学院工学府

E-mail: 3te09065m@s.kyushu-u.ac.jp 
ド最適化手法を開発した ${ }^{(4)}$. この手法は，擬似焼き鈍し法 (SA)に基づいて多点同時探索を行う計算手続きに遺伝 的アルゴリズム $(\mathrm{GA})$ の計算手続きを導入した手法であり，以下，これを SA/GA ハイブリッド最適化手法と呼ぶ 。 SA/GA ハイブリッド最適化手法では，SAの計算手続きにより生成された探索個体およびチャンピオンデータ (非 劣解の集合) の情報を利用して遺伝的操作手続きを行い，新しい探索個体を生成する．乥して，光れらを初期探 索個体として再度 SA の計算手続きを実行する .この方法によれば, 再アニーリングを行う通常のSA に比べて最

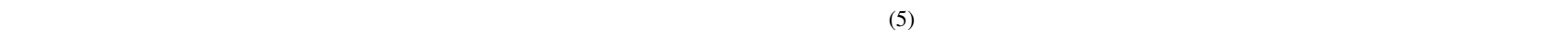
成された解を位相の種類毎に分類した上で, 保存する解の個数に上限を設けることにより必要な計算メモリ量の 低減化を図るとともに，遺伝的操作手続きのなかで最も重要な親個体の選択法について検討を行った．弚の結果， 新たに定義した希少度と呼ばれる評価指標を用いた選択法によれば，解の多樣性を維持しつつパレート最適フロ ントを効率的に求めることができることを確認した．

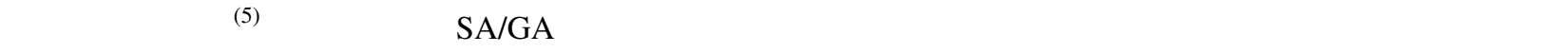

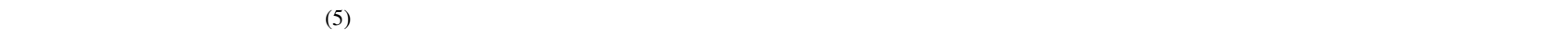
点座標はすべて产の格子点上に置いている .このため，格子点の間隔 (メッシュサイズ) を小さく設定するほど， 骨組構造の細密な形状を求めることができる. しかしながら, 格子点数か増加すれば, 生成可能な探索個体の数が 膨大となる上, 局所解の数も増加するため, 探索個体がパレート最適フロントへ収束しにくくなってしまう. 乥こ で本報では，この問題の対策として，初期の段階ではメッシュサイズを大きく設定して計算を開始し，SA および GA による繰り返し計算を実行する過程でメッシュサイズと節点の移動範囲とを段階的に小さくしていく方法を新 たに導入する.以下ではこの方法をメッシュサイズ変更法と呼ぶ .このような操作によれば, 生成可能な探索個体 の数を少なく抑えることができるので, 探索個体が局所解に滞ることを回避しつつ, 効率良くパレート最適フロ ントが得られることが期待できる．本報では，具体的な数値計算結果を基に提案手法の有効性について検証する．

\section{2. 定 式 化}

本報では, 既報 ${ }^{(5)}$ と同樣に, 図 1 に示すような 2 次元骨組構造物の位相・形状同時多目的最適化問題を対象と して取り扱う.このモデルでは, $2 L[\mathrm{~m}] \times H[\mathrm{~m}]$ の範囲を設計領域とし, 兴の中に複数の部材要素からなる骨組構 造を設ける. 図 1 に示す骨組構造は光の基本形状の一例である. 図中の実線は部材要素を示し, 部材要素は全て 同じ断面積をもった一樣断面直線はり (以下，一樣はりと呼ぶ）であるものとする . 図中の黑丸は部材要素同士 の結合部を示しており，以下，これを節点と呼ぶ . 部材要素同士はこの節点において剛結合しているものとする 本報の計算モデルでは，各節点は設計領域内に設けた間隔 $d_{m}$ の正方格子点上にのみ存在し得るものとし，節点の 配置に応じて樣々な位相や形状を形成する(6). ただし，図中に示した節点 $\mathrm{a}, \mathrm{b}$ は基礎にピン支持された固定点であ り，節点 $\mathrm{c}, \mathrm{d}$ は赤線で示した中心軸上の格子点にのみ存在できるものとする . 兴の他の節点については常に中心 軸を基準として左右対称となるように配置される .

本報では, 節点の位置を設計変数として構造質量 $M$ の最小化と 1 次の固有振動数 $f$ の最大化を目的関数とする 2 目的最適化を行う.なお，上記のような 2 次元骨組構造物の面内自由振動を考えると，一般的に縦・曲げ連成振 動が発生するため, 1 次の固有振動数を求める自由振動解析では, 面内縦・曲げ連成振動を取り扱う.また, 静荷

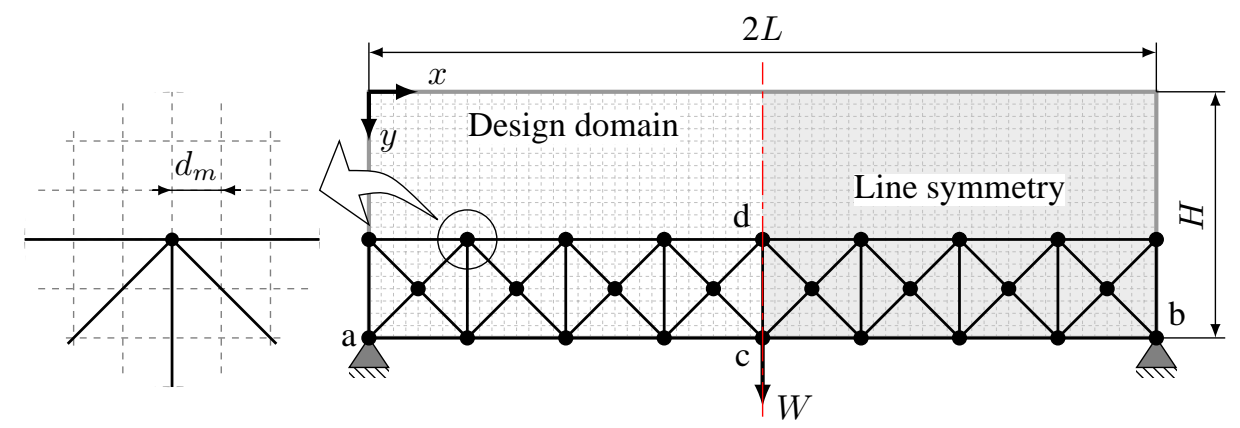

Fig. 1 Computational model 
重 $W$ が節点 $\mathrm{c}$ に鉛直方向に作用するものとし，静たわみおよび応力に関する制約条件を次式のように設定する．

$$
\delta_{\max } \leq \delta_{a}, \sigma_{\max } \leq \sigma_{a}, \tau_{\max } \leq \tau_{a}
$$

ここに, $\delta_{a}$ は静たわみの制限值， $\sigma_{a}$ は許容曲げ応力 , および $\tau_{a}$ は許容せん断応力である . 各一樣はりの共通の 断面積は，式 (1)の制約条件をすべて満足する最小値として，後述する探索個体毎に静解析により決定される．い ま, 設計領域内に $q$ 個の節点が存在するものとして, 各節点の座標を設計変数にとり, 設計変数べクトルを次の ように表す．

$$
\boldsymbol{Z}=\left\{\boldsymbol{z}_{1}, \boldsymbol{z}_{2}, \cdots, \boldsymbol{z}_{q}\right\}, \boldsymbol{z}_{j}=\left(x_{j}, y_{j}\right)
$$

ここに, $\boldsymbol{z}_{j}$ は節点 $j$ の設計変数である .このとき , 最適化問題は次式のように定式化される .

$$
\left.\begin{array}{l}
\text { Find } \boldsymbol{Z} \\
\text { to minimize } M(\boldsymbol{Z}) \text { and maximize } f(\boldsymbol{Z}) \\
\text { subject to } \delta_{\max } \leq \delta_{a}, \sigma_{\max } \leq \sigma_{a}, \tau_{\max } \leq \tau_{a}
\end{array}\right\}
$$

\section{SA/GA ハイブリッド最適化手法}

本報で提案する手法は, メッシュサイズの変更に関する部分以外の計算アルゴリズムは既報 ${ }^{(5)}$ で提案した SA/GA ハイブリッド最適化手法 (以下, 従来法と呼ぶ) と同樣である. 乥こでまず, 本章では従来法と共通する計算アル ゴリズムの概要について述べる.詳細については文献 ${ }^{(5)}$ を参照されたい .なお , 説明にあたり，以下では，2つの 異なる設計变数べクトル $Z^{i}, Z^{i^{\prime}}$ について产れ光れの目的関数を比較したとき，

$$
f\left(\boldsymbol{Z}^{i}\right) \leq f\left(\boldsymbol{Z}^{i^{\prime}}\right) \wedge M\left(\boldsymbol{Z}^{i}\right) \geq M\left(\boldsymbol{Z}^{i^{\prime}}\right)
$$

であれば $Z^{i} を Z^{i^{\prime}}$ の劣解， $Z^{i^{i}}$ を $Z^{i}$ の非劣解と呼ぶ . さらに，他のいずれの解に対しても非劣解となる解はパ レート最適解であり，光のような解の集合をパレート最適フロントと呼ぶ .

\section{$3 \cdot 1$ 従来法の概要}

従来法の計算手続きの概要を図 2 に示す. 従来法は, 複数の探索個体を用いて多点同時探索を行うSA の計 算手続きの中に GA による初期探索個体の生成アルゴリズムを導入した手法である.SA では， $N$ 個の探索個体 $i(i=1, \cdots, N)$ か独立して次のような方法て最適解の探索を行う. まず，探索個体 $i$ (設計变数 $\boldsymbol{Z}^{i}$ ) の節点 $j$ の 座標を確率的な方法で近傍の格子点へ移動させた近傍解 (設計変数 $\tilde{Z}^{i}$ ) を生成する. 次に , $\tilde{Z}^{i}$ の目的関数を $Z^{i}$ およびチャンピオンデータの目的関数と比較する. 光して,$\tilde{Z}^{i}$ が非劣解であれば $\tilde{Z}^{i}$ を新しい設計変数 $Z^{i}$ に置き 換え，弚の他の場合には置換確率 ${ }^{(5)}$ を用いて置き換えるか否かを判定する．また，更新された探索個体 $i$ が弚の 時点でのパレート最適解である場合には, 弚の探索個体を位相毎に分類した上でチャンピオンデータとして保存 する . 以上の一連の計算手続きを全探索個体の固定点を除くすべての節点に対して実行することを SA における 1 ステップと呼ぶ．さらに，SAによる探索個体の更新回数に基づいた終了条件 ${ }^{(5)}$ を定義し，この条件を満たすまで SA の計算手続きを繰り返し行うことを 1 世代と呼ぶ . 次に 1 世代分の計算手続きが終了した時点で, 次世代の 初期探索個体を生成するために GA の遺伝的操作手続きを行う .この遺伝的操作手続きではまず, 前世代までに得 られた位相毎に分類されているチャンピオンデータと $N$ 個の探索個体から評価関数に基づいて親個体 1 と親個体 2 のペアを $N / 2$ 組選択する . 導入した選択法については後述する .さらに，選択した親個体の組毎に交叉を行い， 新たに生成された $N$ 個の個体を次世代の SA の初期探索個体とする .

以上の一連の計算手続きを，規定の世代数に至るまで繰り返し行い，最終世代の SA の計算手続きか終了した時 点で得られたチャンピオンデータをパレート最適フロントとみなす．

1st generation 2 2nd generation $3 r$ generation

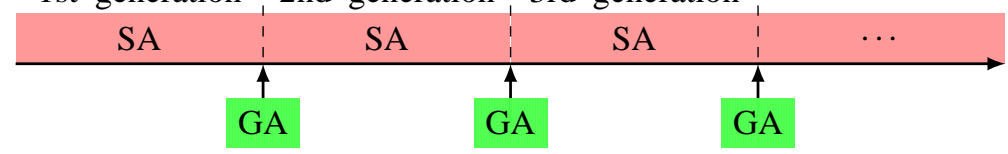

Fig. 2 Concept of SA/GA hybrid optimization method 


\section{2 遺伝的操作手続き}

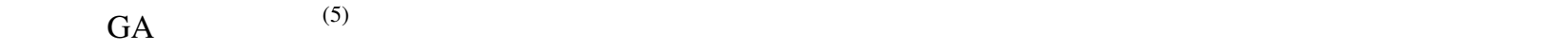
確認された親個体の選択法を用いる.この選択法の具体的な計算手続きは次の通りである.まず，GA の遺伝的操 作で用いる親個体を選択するために，親個体候補の集合 $W_{c p}$ をチャンピオンデータおよび探索個体から生成する． 弚の際, チャンピオンデータが探索個体の数よりも多く発生する場合が多いため, 両者からの選択確率を等しく するために，探索個体とチャンピオンデータの個体数がほぼ等しくなるようにチャンピオンデータの部分集合を 生成し，これと探索個体の和集合を親個体候補の集合 $W_{c p}$ とする．次に， $W_{c p}$ が位相別に分類されていることを 利用して，位相の多樣性を確保しつつ優秀な解を生成するために，親個体 1 を希少度と呼ばれる関数を用いて選 択する．いま，個体 $i$ の非劣解となる解の個数に 1 を足した值を個体 $i$ のランク $R^{i}(\geq 1)$ とし ${ }^{(7)}$ ，集合 $W_{c p}$ 内に おける同一位相毎の個体数の比を $\Theta_{t}$ (下添え字 $t$ は位相の種類番号を表す) とするとき, 位相 $t$ に含まれる個体 $i$ の希少度 $R a_{t}^{i}$ は次式のように定義される．

$$
R a_{t}^{i}=\frac{1}{R^{i} \Theta_{t}}
$$

これにより，ランクの值が小さく，個体数の割合が小さい位相を持った個体が親個体 1 として選択されやすくな る.このようにして，探索個体数の半分の個数だけ親個体 1 を選択した後，親個体 1 毎にペアとなる親個体 2 を $W_{c p}$ の中からランダムに選択する . 交叉に関しては, 上記の方法で選択された親個体のペアに対して , 交叉確率 $p_{\text {cross }}$ に基づく 2 点交叉を行う.

\section{4.メッシュサイズ変更法の導入}

前章で述べた従来法では, 得られる最適解の形状の細密化を図るためにメッシュサイズを小さく設定すると SA の計算手続きにおいて生成可能な探索個体の数が膨大となるとともに局所解に滞りがちになり，真のパレート最 適フロントを求めることが困難になる．光こで本報では，この問題の対策として，従来法の計算アルゴリズムに

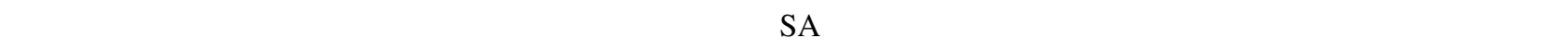
では移動する節点の周辺に円形の節点移動範囲を設けていたが , メッシュサイズ変更法では節点の周辺に正方形 の節点移動範囲を設け，光の中にある格子点へランダムに節点を移動させることとする．ただし，節点移動範囲 の大きさはメッシュサイズの変更に伴い変化するものとする . また , 従来法では節点の周辺に円形の結合範囲を 設けていたが, メッシュサイズ変更法では節点の周辺に正方形の結合範囲を設け，弚の領域内に複数の節点が存 在した場合には光れらの節点を結合する . これ以外の SA および GA に関する計算手続きについては，基本的に 3 章で述べた従来法と同樣である.

\section{$4 \cdot 1$ メッシュサイズの変更手続き}

メッシュサイズ変更法は, 計算の初期段階におけるメッシュサイズ (以下 , 初期メッシュサイズと呼ぶ) を大き く設定して計算を開始し，SA およびGA による繰り返し計算を実行する過程でメッシュサイズ，設計領域，およ び節点の移動範囲とを段階的に縮小していく方法である .この方法の概要を図 3 に示すとともに，具体的な計算 手順を以下に述べる.

1. 計算条件として，大きさ $2 L[\mathrm{~m}] \times H[\mathrm{~m}]$ の設計領域を設定し，設計領域内に設ける正方格子の目標とする間 隔 (最小メッシュサイズ) $d$ および初期メッシュサイズ $d_{0}$ を定める .さらに , 本論文におけるメッシュサイ ズ変更法では, 一定の世代数 ( $\hat{g}$ 世代) だけ計算が終了する度にメッシュサイズを半分の長さに取り直す . こ のため , メッシュサイズの変更回数を $\mu$ とするとき , 初期メッシュサイズは $d_{0}=2^{\mu} d$ となる .

2. 図 4(a) に示すようにメッシュサイズ $d_{0}$ の正方格子を設けた設計領域内に $N$ 個の初期探索個体を置き，さら に，SA の計算手続きにおける辺長 $r_{0}\left(>2 d_{0}\right)$ の正方形の節点移動範囲を各節点に設ける. 光して，3 章で述 べた従来法と同樣の計算手続きを 1 世代から $\hat{g}$ 世代まで実行する .

3. $\hat{g}$ 世代目の GA による計算を実行した後，設計領域内のメッシュサイズを $d_{0}$ から $d_{1}=d_{0} / 2$ に変更する.さ

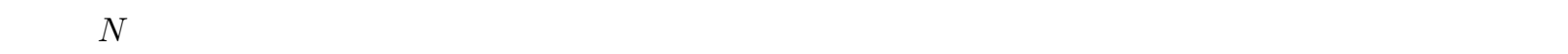
ま，図 4(b) に示すような探索個体が得られているものとする .このとき，設計領域内の移動可能な全ての節 点 (図中，赤色，青色，緑色で示した節点) に対して，図 4(c) に示すように $L / 2[\mathrm{~m}] \times H / 2[\mathrm{~m}]$ の大きさを持っ 


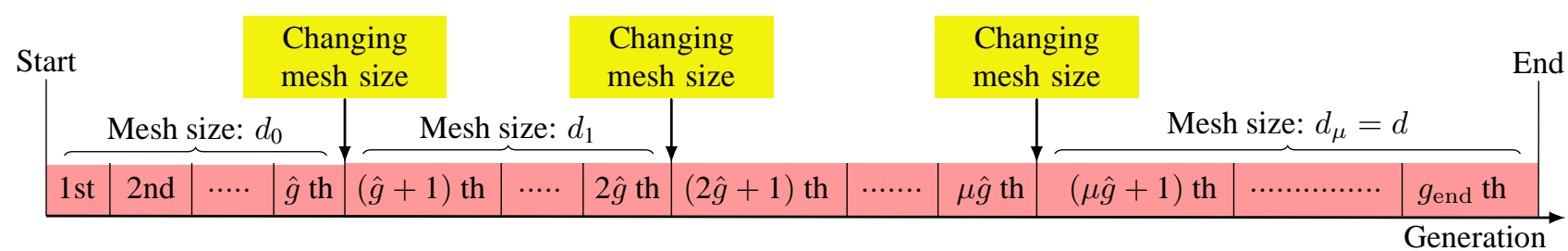

Fig. 3 Procedure of mesh size change

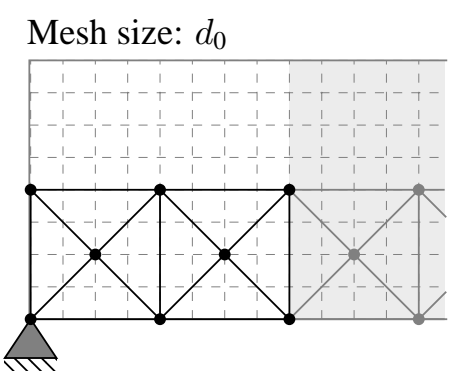

(a)

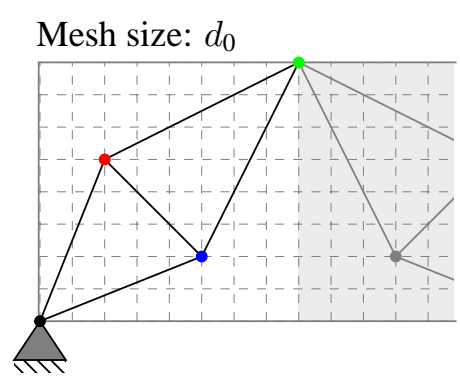

(b)

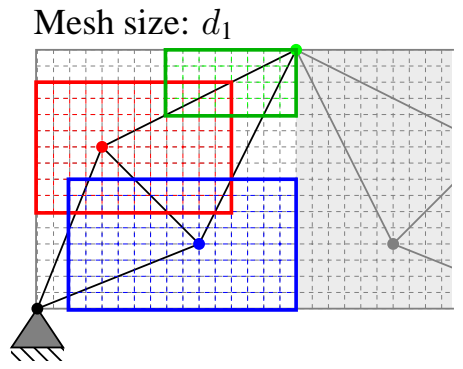

(c)

Fig. 4 Resetting mesh size and design domain

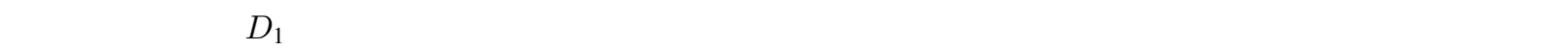
重なってもよいが , 手順 (1) て設定した元の設計領域よりも外側の領域については節点の移動範囲から除外す るものとする．また，節点移動範囲の辺長についても $r_{0}$ から $r_{1}=r_{0} / 2$ に変更する .

4. 上記 (3)によりすべての探索個体のメッシュサイズおよび設計領域を変更した後,$\hat{g}+1$ 世代から $2 \hat{g}$ 世代ま で計算を実行する．との際，SA による計算手続きでは，節点毎に設けた局所設計領域の範囲内で節点を移動 させることによって探索個体の近傍解を生成する．また，GAの操作によって新たに探索個体が生成された場 合 , 上記 (3) と同樣にして節点毎に局所設計領域 $D_{1}$ を設ける .

5. $2 \hat{g}+1$ 世代目以降の計算についても, 上記 (3),(4) と同樣に, $\hat{g}$ 世代毎にメッシュサイズおよび設計領域の変 更を行いながら SA およびGA の計算を繰り返し実行する.いま， $m \hat{g}$ 世代まで計算が終了し， $m$ 回目のメッ シュサイズ変更手続きを行う場合, メッシュサイズ $d_{m}$, 局所設計領域 $D_{m}$ および節点移動範囲の辺長 $r_{m}$ は 光れ光れ次式のようになる。

$$
\begin{gathered}
d_{m}=\frac{d_{0}}{2^{m}} \\
D_{m}=\left(\frac{L}{2^{m}}, \frac{H}{2^{m}}\right) \\
r_{m}=\frac{r_{0}}{2^{m}}
\end{gathered}
$$

6. $\mu \hat{g}$ 世代目において $\mu$ 回目のメッシュサイズの変更を行った段階で, メッシュサイズが最小メッシュサイズ $d$ となる .これ以降の計算ではメッシュサイズや設計領域の変更を行わず，最終世代 $g_{\text {end }}$ まで SA および GA の 計算を繰り返し実行する。

このようにメッシュサイズ変更法では，初期段階においてメッシュサイズを大きく設定すること，および段階 的にメッシュサイズを小さくする過程において局所設計領域と節点の移動範囲の辺長とを同時に縮小することに より，計算の各段階において生成可能な探索個体の数をなるべく小さく抑えることが可能である .これにより，最 終的なメッシュサイズを小さく設定した場合でも，局所解に滞りにくくなり，細密な形状をもった最適解を効率良 く探索することが期待できる .

$4 \cdot 2$ 位相と形状の変更ルール

本手法では, 従来法と同樣に連続的位相変化モデル ${ }^{(6)} に$ 類似した考え方に基づいて節点の結合や分離を行うこと で探索個体の位相と形状を同時に変化させる .メッシュサイズ変更法では, 節点の周辺に辺長 $\delta_{r}$ の正方形の結合 範囲を設ける.いま，図 5(a) に示すような探索個体において，赤色の節点を移動させた結果，青色の節点を中心 


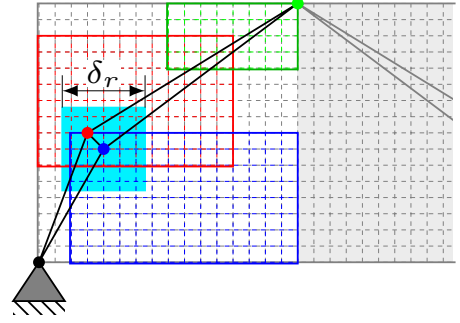

(a)

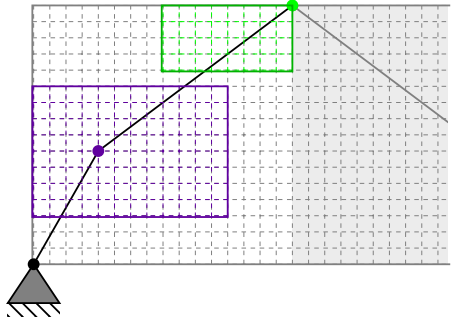

(b)

Fig. 5 Node integration rule

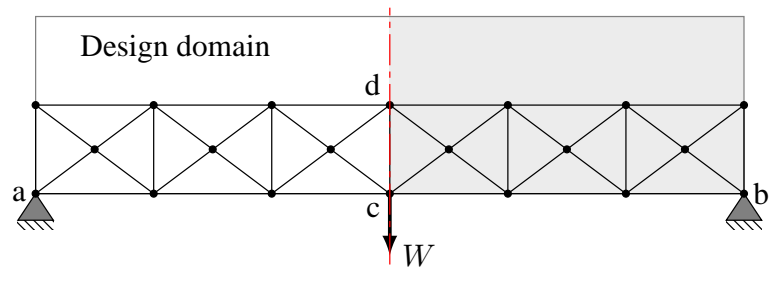

Fig. 6 Model 1

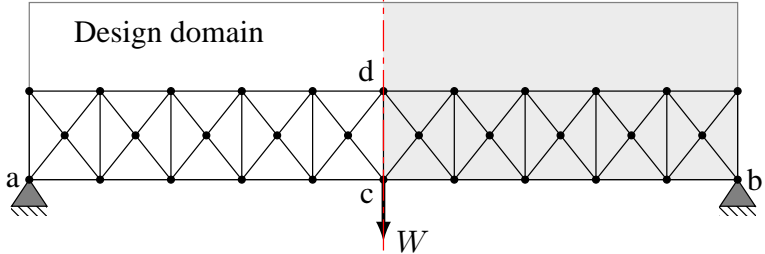

Fig. 7 Model 2

Table 1 Configuration parameters of SA/GA hybrid optimization

\begin{tabular}{ccc|cccc|ccc|cc|c}
\hline$\delta_{a}$ & $\sigma_{a}$ & $\tau_{a}$ & $r_{0}$ & $\delta_{r}$ & $N$ & $\hat{N}$ & $T_{0}$ & $\eta$ & $s$ & $\hat{\varphi}$ & $p_{\text {cross }}$ & $\hat{g}$ \\
\hline $4 \mathrm{~cm}$ & $217 \mathrm{~N} / \mathrm{m}^{2}$ & $125 \mathrm{~N} / \mathrm{m}^{2}$ & $1.2 \mathrm{~m}$ & $0.6 \mathrm{~m}$ & 100 & 100 & 10 & 0.98 & 10 & 5 & 0.8 & 50 \\
\hline
\end{tabular}

とする節点結合範囲内に移動したとする .このとき，図 5(b) に示すように両節点間の中間点に最も近い格子点に 両節点を移動させ, 1 個の節点に結合する .メッシュサイズ変更法では , 結合した節点の位置を中心として局所設 計領域を取り直す．結合した節点は，節点が再び分離するまでは同じ局所設計領域内で移動するものとする．な お，3つ以上の節点が互いに結合範囲内に存在する場合も同樣に処理する . 一方 , 節点の移動に伴って結合されて いた節点が結合範囲外に出た場合には，節点同士を分離した上で光れぞれの節点毎に局所設計領域を取り直す．

\section{5.メッシュサイズ変更法の効果の検討}

図 6 および図 7 に示す 2 種類のモデル (Model 1, Model 2) を対象として最適化計算を行った . 両モデルとも $12 \mathrm{~m} \times 3 \mathrm{~m}$ の設計領域にメッシュサイズが $15.625 \mathrm{~mm}$ の正方格子を設け，光の中に，Model 1 では節点数 20 の基 本構造を, Model 2 では節点数 32 の基本構造を図に示すように設定した . なお，設計領域の大きさやメッシュサ イズに関しては, メッシュサイズ変更法の適用が容易となるように設定した . 系内の一樣はりは全て鋼製で, 内 外径比 0.8 の中空丸棒とした . 節点 $\mathrm{a}, \mathrm{b}$ は, ばね定数 $10^{15} \mathrm{~N} / \mathrm{m}$ のせん断ばね要素によってピン支持し, 節点 $\mathrm{c} に$ は $W=25 \mathrm{kN}$ の静荷重が鉛直方向に作用するものとした . 制約条件および最適化計算に関するパラメータを表 1 に示す .ここに, $\hat{N}$ はチャンピオンデータとして保存できる位相毎の個体数の上限值， $T_{0}$ は温度パラメータの初 期値, $\eta$ は温度更新係数, $s$ はSA の収束判定で用いられる探索個体の改善割合の観測数, $\hat{\varphi}$ は希少度の計算に用 いられる䦨值， $p_{\text {cross }}$ は交叉確率である .これらのパラメータの役割と意味については文献 ${ }^{(5)}$ を参照されたい．制 約関数および目的関数の計算に対しては, 骨組構造の各一樣はりを適切に分割し, 集中系にモデル化した上で一 般化伝達剛性係数法 ${ }^{(8)}$ を適用している.

本報では, 従来法 (Conv.) と従来法にメッシュサイズ変更法を導入した方法 (以下では, これをメッシュサイズ変 更法と呼ぶ）の計算性能について比較を行う.解析にあたり，従来法では Model 1, Model 2 ともにメッシュサイズを $15.625 \mathrm{~mm}$ に設定した . 一方, メッシュサイズ変更法では従来法に合わせて最小メッシュサイズを $d=15.625 \mathrm{~mm}$ とし，初期メッシュサイズ $d_{0}$ は $500 \mathrm{~mm}, 250 \mathrm{~mm}, 125 \mathrm{~mm}, 62.5 \mathrm{~mm}, 31.25 \mathrm{~mm}$ の 5 通りに設定した（以下，弚れ 攵れMesh(500), Mesh(250), Mesh(125), Mesh(62.25), Mesh(31.25) と呼ぶ）。光して，光れ光れの手法により500世

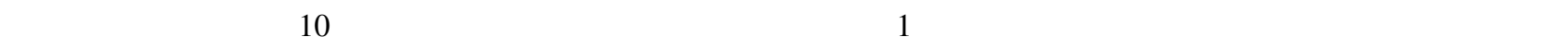
造をもつ $N$ 個の初期探索個体を与えて計算を開始した .なお，本報の例題程度の規模であっても，総当たり計算 
を実施して真の最適解（パレート最適フロント）を得ることは計算量的に極めて困難であるため，各手法による 試行計算で得られた全ての計算結果から非劣解の集合を選択し，これを近似的にパレート最適フロントとみなす。

\subsection{Model 1 の計算結果}

\section{$5 \cdot 1 \cdot 1$ パレート 最適フロント}

まず, 図 6 に示す Model 1 を対象として,各手法により最適化計算を行い, 得られた全ての結果を統合してパ

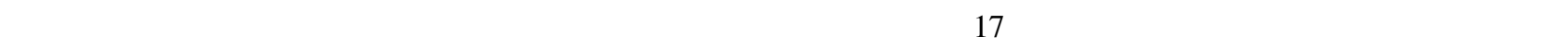
位相の種類を $G_{1}$ から $G_{17}$ で区別し，位相の種類毎の代表的な形状を図 8 に，目的関数空間における位相別のパ レート最適フロントを図 9 に示す. 各手法による試行計算の結果を比較したところ, チャンピオンデータのラン クや位相の種類に関して手法毎に差違が見られた .

図 10 は, 各手法で最終世代までに得られた $G_{10}$ の位相に関するチャンピオンデータを目的関数空間上にプロッ トした結果である .ここに , 図中の黑色の点は 10 回の試行計算で得られた全てのチャンピオンデータを示し，赤 色の点はパレート最適フロントに対応する最適解を示す . 従来法の結果を見ると，試行計算毎の結果のばらつき が大きくなっており，いずれの試行計算でもパレート最適フロントに含まれる最適解は求められていない，一方， メッシュサイズ変更法の結果でも試行計算毎のばらつきは生じているものの，従来法に比べると光の程度は小さい . また ,メッシュサイズ変更法は従来法に比べて全体的に優れたチャンピオンデータが得られており，Mesh(125), $\operatorname{Mesh}(250)$ ではパレート最適フロントに含まれる最適解が求められている．この他の位相に関するチャンピオン データについても多くの位相で同樣の傾向が見られることを確認している .

表 2 は, 各手法においてパレート最適フロントを構成する位相が求められた試行計算の回数を位相の種類毎に 示している.ただし，図 10 に示したように，たとえパレート最適フロントを構成する位相が求められていても， 弚のチャンピオンデータがパレート最適フロントに到達しているとは限らない .この結果から, 求められる位相 の種類に関しても，手法毎にばらつきが大きいことがわかる．とくに, 図 10 で示した $G_{10}$ の位相に関しては, 各 手法で試行計算によらず良く求められているものの， $G_{9}, G_{11}, G_{14}, G_{15}, G_{16}, G_{17}$ などの位相は手法によっては 1 度も求められていないものもある.

以上のことから，従来法とメッシュサイズ変更法の結果には何らかの有意な差違があると考えられる．弚こで， 両手法の計算性能について計算効率や計算精度の観点から具体的に評価するために, 以下のような評価指標を導 入する .

(a) チャンピオンデータの個数＼cjkstart試行計算毎の各世代においてチャンピオンデータの個数を求め, 弚の平均值 を $N_{\text {all }}$ とする

(b) ランクの平均值＼cjkstart従来法およびメッシュサイズ変更法の全ての試行計算について, 世代毎のチャンピオ ンデータをすべて保存しておき , パレート最適フロントを基準として , 全てのデータに対してランクの值 ${ }^{(7)}$ を計算する .さらに，得られたランクの值について試行計算毎に各世代のランクの平均值を求める. 乥して， 手法毎に得られた各世代のランクの平均值の平均をとった值を $\bar{R}$ とする . パレート最適フロントに近いほど $\bar{R}$ の值が小さくなるので, これにより各世代においてどの程度パレート最適フロントに近い解が得られてい るかを評価することができる .

(c) 位相の個数＼cjkstart試行計算毎の各世代においてチャンピオンデータに含まれている位相の個数を求め, 兴の平 均値を $N_{G}$ とする . $N_{G}$ が大きいほど，多樣な位相がチャンピオンデータに含まれていることを示す．

(d) パレート最適フロントに含まれる位相の個数＼cjkstart試行計算毎の各世代のチャンピオンデータに含まれる位 相のうち, パレート最適フロントに含まれる位相の個数を求め, 光の平均值を $N_{G o p t}$ とする.$N_{G}$ との差が 少ないほど，発生した位相の多くがパレート最適フロントに含まれているといえる．

また , チャンピオンデータの収束の程度を評価するため, 次のような指標を定める ${ }^{(9)}$.いま,$g-1$ 世代および $g$ 世代の最終ステップまでに得られたチャンピオンデータの集合を光れ光れ $P_{g-1}$ および $P_{g}$ とする .このとき, $P_{g-1}$ および $P_{g}$ の和集合をとり，光れ元れの解のランクを求めて非劣解を抽出する. 光して， $P_{g-1}$ に含まれる全要素 数に対して $P_{g-1}$ の中から非劣解として抽出された要素数の割合を求める. 以下では，この割合を $g$ 世代目におけ るチャンピオンデータの収束率と呼ぶ。 すなわち, 収束率が 1 に近い值となっていれば, 弚の世代において新た 


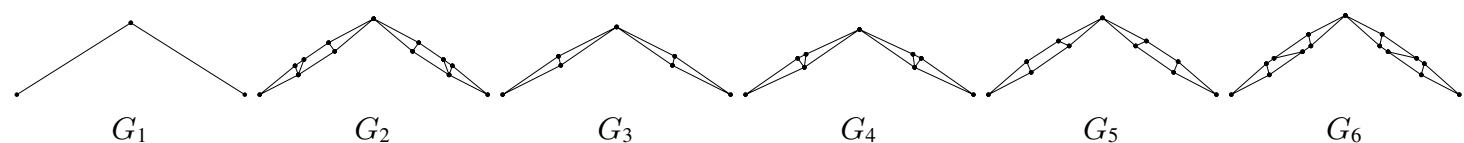

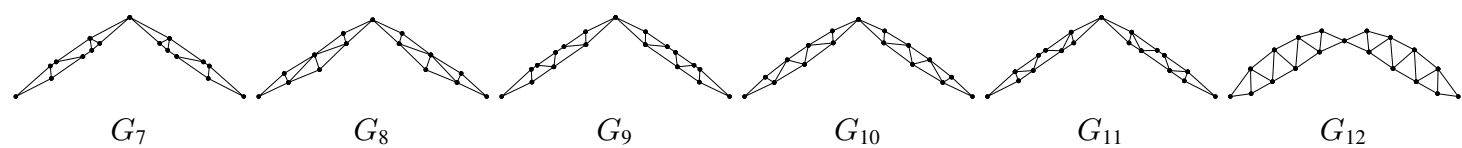

$G_{7}$

$G_{8}$

$G_{9}$

$G_{10}$

$G_{11}$

$G_{12}$

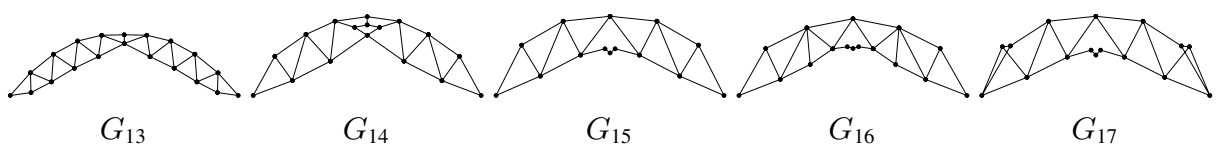

Fig. 8 Optimal topology of Model 1

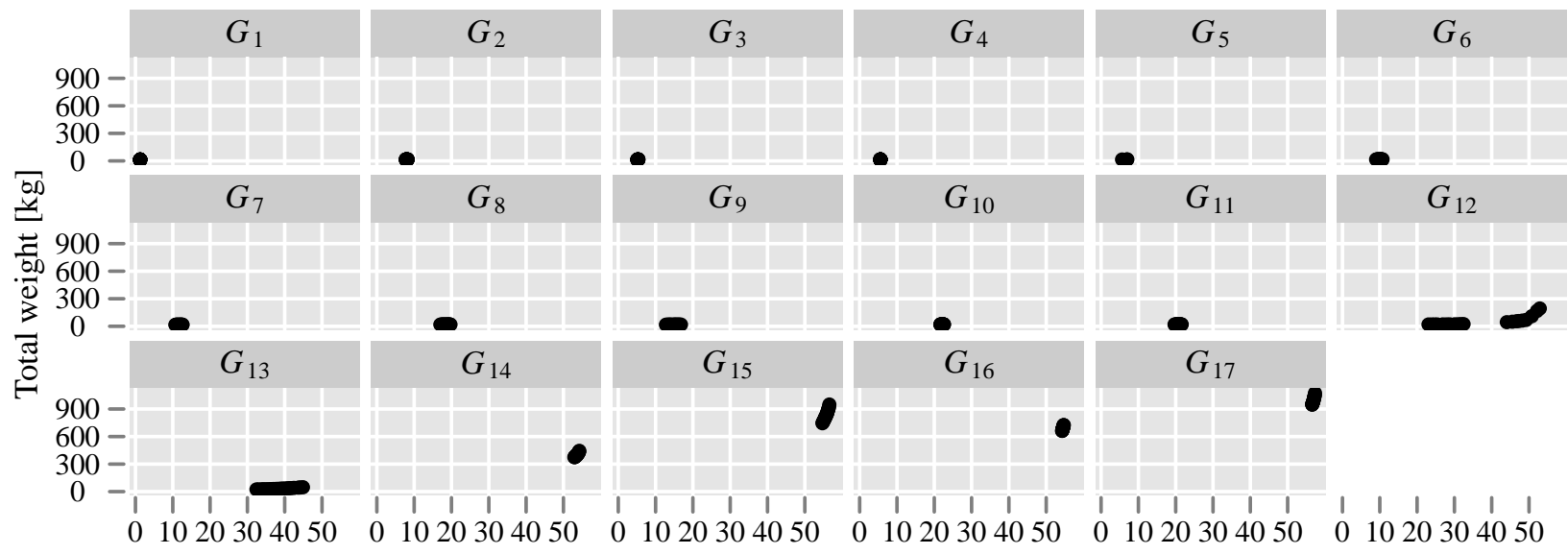

First natural frequency $[\mathrm{Hz}]$

Fig. 9 Pareto optimal solutions of Model 1

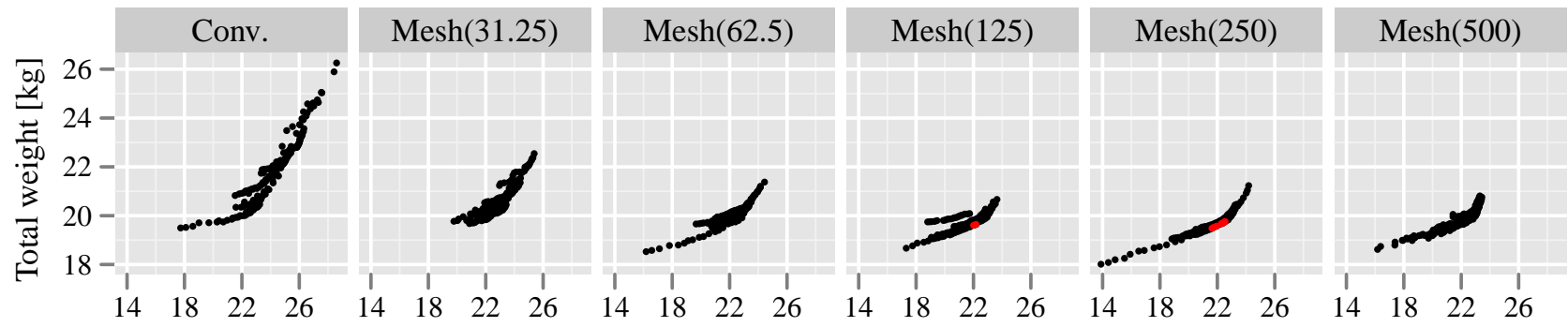

First natural frequency [Hz]

Fig. 10 Champion data in $G_{10}$ obtained by 500th generation (Model 1)

Table 2 Comparison of the number of testruns in which each optimal topology was obtained by 500th generation

\begin{tabular}{l|ccccccccccccccccc}
\hline Method & $G_{1}$ & $G_{2}$ & $G_{3}$ & $G_{4}$ & $G_{5}$ & $G_{6}$ & $G_{7}$ & $G_{8}$ & $G_{9}$ & $G_{10}$ & $G_{11}$ & $G_{12}$ & $G_{13}$ & $G_{14}$ & $G_{15}$ & $G_{16}$ & $G_{17}$ \\
\hline Conv. & 10 & 5 & 6 & 7 & 2 & 1 & 0 & 4 & 0 & 9 & 0 & 4 & 1 & 1 & 1 & 1 & 1 \\
$\operatorname{Mesh}(31.25)$ & 10 & 2 & 10 & 7 & 2 & 0 & 0 & 5 & 0 & 9 & 0 & 5 & 2 & 0 & 0 & 0 & 0 \\
$\operatorname{Mesh}(62.25)$ & 10 & 4 & 9 & 8 & 1 & 0 & 0 & 7 & 0 & 8 & 0 & 8 & 5 & 0 & 0 & 0 & 0 \\
$\operatorname{Mesh}(125)$ & 10 & 6 & 8 & 8 & 0 & 0 & 0 & 3 & 0 & 9 & 0 & 7 & 4 & 0 & 0 & 0 & 0 \\
$\operatorname{Mesh}(250)$ & 10 & 8 & 3 & 2 & 0 & 3 & 3 & 3 & 1 & 10 & 2 & 7 & 4 & 0 & 0 & 0 & 0 \\
$\operatorname{Mesh}(500)$ & 10 & 10 & 2 & 0 & 2 & 4 & 2 & 1 & 0 & 10 & 1 & 7 & 2 & 0 & 0 & 0 & 0 \\
\hline
\end{tabular}




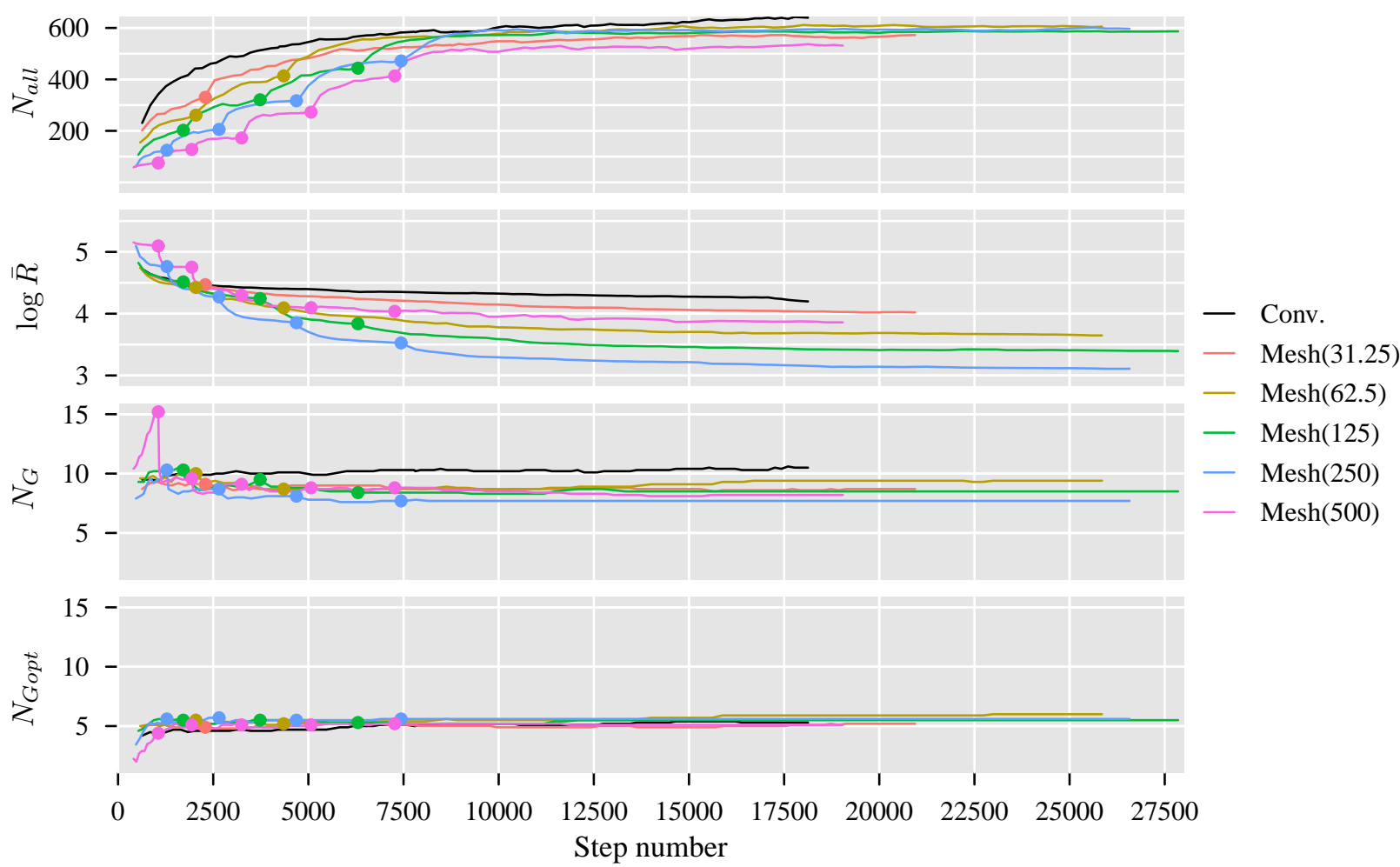

Fig. 11 Performance indicators of each method (Model 1)

なパレート最適解が発見されにくくなっているものと判断できる.

5.1.2 評価指標を用いた性能の検討

前項で述べた評価指標を用いて従来法とメッシュサイズ変更法の計算性能の比較を行った ·まず，各手法の試行 計算で得られた計算結果に対して 4 種類の評価指標を求めた結果を図 11 に示す. SA/GAハイブリッド最適化手法 の計算手続きでは，探索個体が改善される頻度に応じて SA の計算を終了させるため，SA の計算回数（ステップ 数) は世代毎に異なる.このため, 図 11 の横軸には各世代における手法毎のステップ数の平均値 (以下 , これを 平均ステップ数と呼ぶ）をとっている．また，縦軸には 4 種類の評価指標を順番に示しているが， $\bar{R} に$ 関しては 視認性を向上させるため対数変換した值 $(\log \bar{R})$ をとっている . また , 凡例に示す通り，曲線の色の違いが手法の 違いを表し , 曲線上の丸印はメッシュサイズか変更された世代であることを意味している .

まず， $N_{\text {all }}$ に関する結果を見ると, ステップ数の全体にかけて従来法の方がメッシュサイズ変更法の計算結果 よりも大きな值をとっている .メッシュサイズ変更法では, 初期メッシュサイズが大きいほど初期の世代でチャ ンピオンデータの個数が少ないようである.しかしながら, メッシュサイズか変更される度に個数が大きく増加 しており，ステップ数が大きくなるにつれて Mesh(62.5), Mesh(125), Mesh(250) では従来法との差はかなり減少し ている．また， $\bar{R} に$ 関する結果を見ると，メッシュサイズ変更法の方が従来法よりも小さくなっている．とくに， $\operatorname{Mesh}(31.25)$ 以外の結果では, 従来法よりもメッシュサイズが大きい段階でも $\log \bar{R}$ の值が従来法よりも小さくなっ ており，Mesh(250)の結果が最も小さい值をとっている．次に， $N_{G}$ に関する結果を見ると，従来法の方がメッシュ サイズ変更法よりもやや大きくなっており，従来法の方が得られる位相の数が多いことがわかる . しかしながら， $N_{\text {Gopt }}$ に関する結果を見ると，両手法の值にあまり差が無いことから，従来法ではパレート最適フロントに含まれ ていない位相が多く求められているのに対して, メッシュサイズ変更法では, 発生した位相の多くがパレート最適 フロントに含まれる位相であることがわかる.以上の結果から , メッシュサイズ変更法のうち Mesh(250)によれ ば, 従来法と同程度の位相の種類数を維持しつつ, 従来法よりもランクの高いチャンピオンデータを数多く求め ることができることがわかる .

次に, 各手法の試行計算で得られた計算結果に対して収束率を求めた . 図 12 は, 10 回の試行計算に対して収束 率の平均值を世代毎に求めた結果である. 図中の横軸は各世代における手法毎のステップ数の平均値であり, 縦軸 


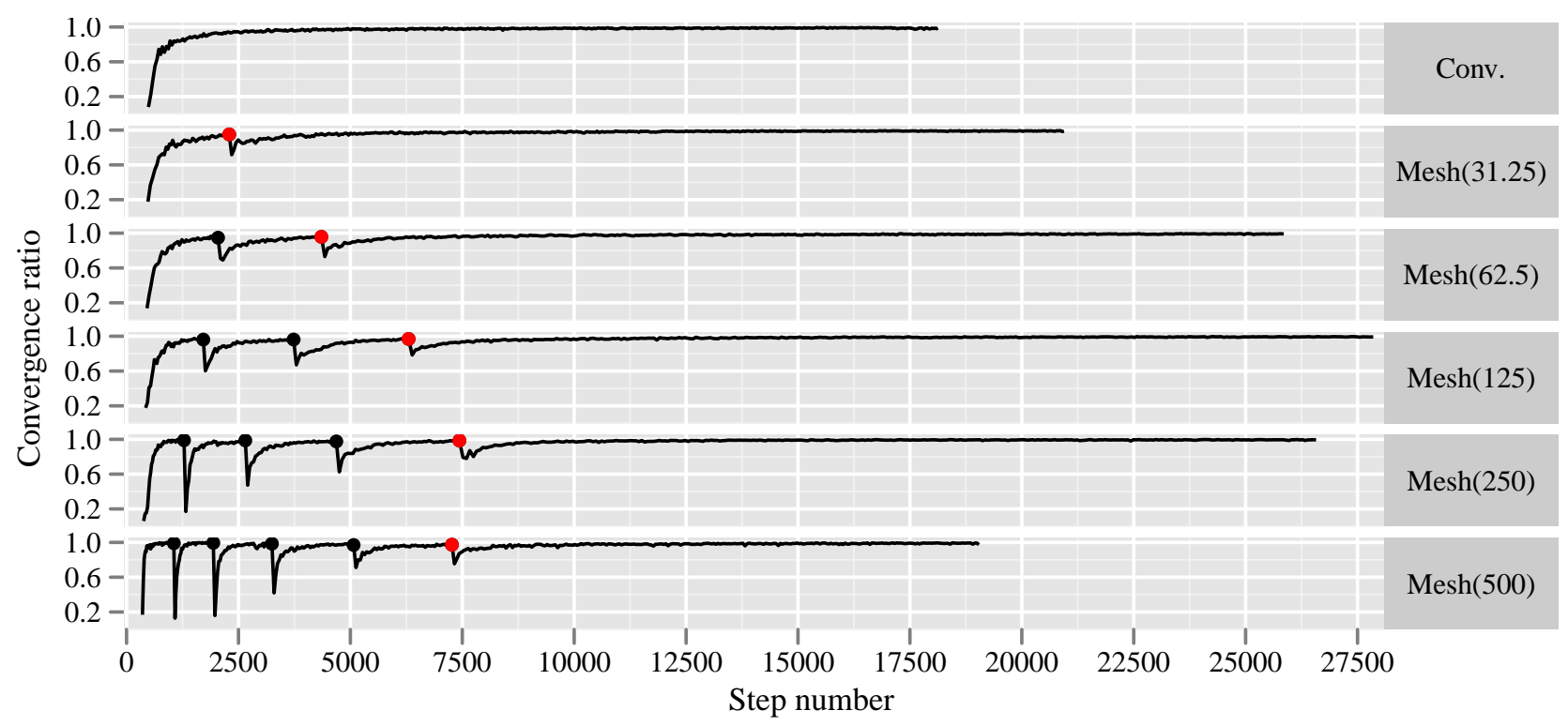

Fig. 12 Convergence ratio of each method (Model 1)

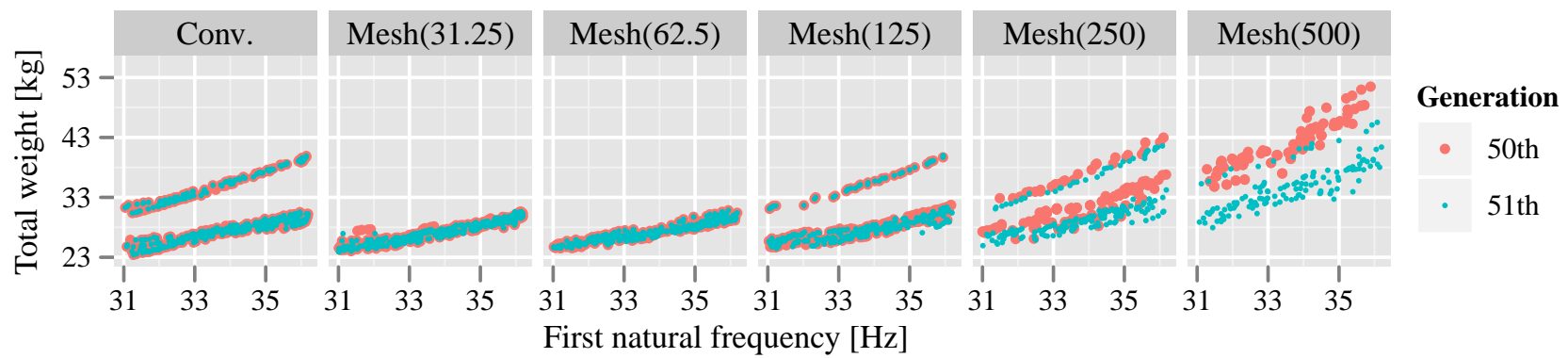

Fig. 13 Champion data obtained before and after changing mesh size

は各世代における手法毎の収束率の平均値をとっている .なお，曲線上の丸印はメッシュサイズの変更点であり， 赤色の丸印は最小メッシュサイズ $d$ に変更される点を示している . まず, 従来法の結果を見ると, 計算開始後すぐ に収束率が大きくなって1の近傍に漸近し，弚のまま最終ステップまで推移している．これに対して，メッシュサ イズ変更法の結果を見ると，従来法と同樣に計算開始後すぐに収束率が 1 の近傍に漸近しているものの，メッシュ サイズが変更されると，弚の度に収束率が一端小さくなっている．とくに，初期メッシュサイズが大きいものほ ど収束率の変化が大きくなっている. 图 13 は , メッシュサイズを変更した前後の世代に相当する 50 世代目と 51 世代目で得られたチャンピオンデータの一部を手法毎に目的関数空間にプロットした結果である . 従来法による 計算結果を見ると，メッシュサイズの変更が行われていないので，50世代目と 51 世代目のチャンピオンデータに はあまり変化が生じていない .一方, メッシュサイズ変更法による結果では, 初期メッシュサイズが大きいもの ほどチャンピオンデータが大きく改善しており，図 12 に示した収束率の変化に対応していることがわかる .この ように, チャンピオンデータに変化が生じた原因の一つとして , メッシュサイズか変更されることによって SAの 計算手続きにおいて生成可能な近傍解が増えることが挙げられる．すなわち，生成可能な近傍解が増えることで 新しい探索個体が生成され易くなり，チャンピオンデータが改善したものと考えられる

表 3 は，各手法における 1 ステップあたりの計算に要する時間の平均値を示している .この結果から，各手法 の 1 ステップあたりの計算時間は同等であるといえる . 乥こで, ステップ数を時間のスケールとして考えて, 従 来法とメッシュサイズ変更法の計算効率について比較した .ただし , メッシュサイズ変更法については, 上述の 考察で最も良好な結果が得られた Mesh(250)のみを比較対象とした .

図 14 は , 500 ステップ, 1500 ステップ, 3000 ステップ, 15000 ステップの 4 つの点において , Mesh(250) と従 来法によって得られたチャンピオンデータの一部分を目的関数空間上にプロットした結果である.ただし，図中に

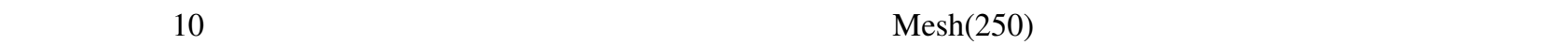


Table 3 Comparison of the CPU time required for the computation per one step

\begin{tabular}{c|cccccc}
\hline Method & Conv. & $\operatorname{Mesh}(31.25)$ & $\operatorname{Mesh}(62.5)$ & $\operatorname{Mesh}(125)$ & $\operatorname{Mesh}(250)$ & $\operatorname{Mesh}(500)$ \\
\hline Time [s] & 1.68 & 1.62 & 1.64 & 1.65 & 1.64 & 1.54 \\
\hline
\end{tabular}
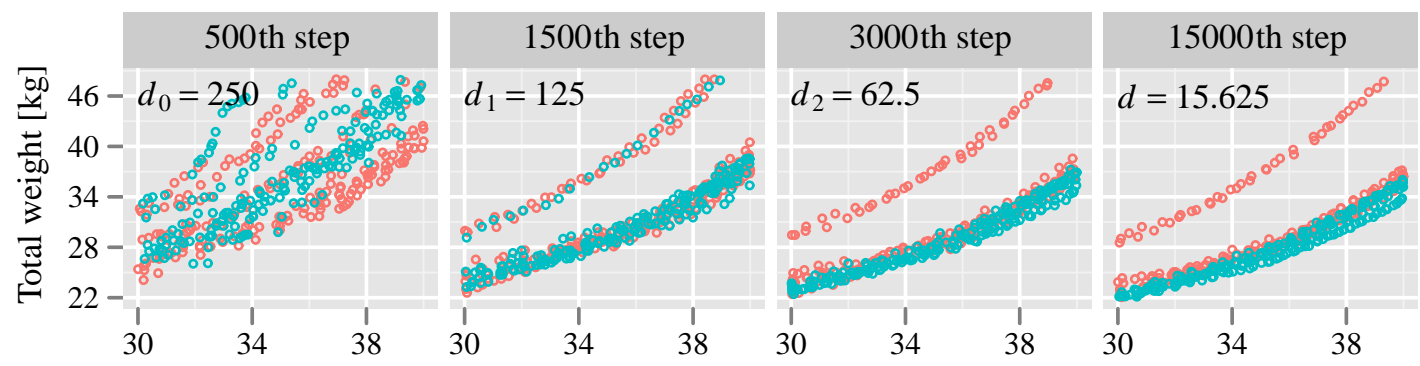

Conv.

$\operatorname{Mesh}(250)$

First natural frequency [Hz]

Fig. 14 Champion data in each step

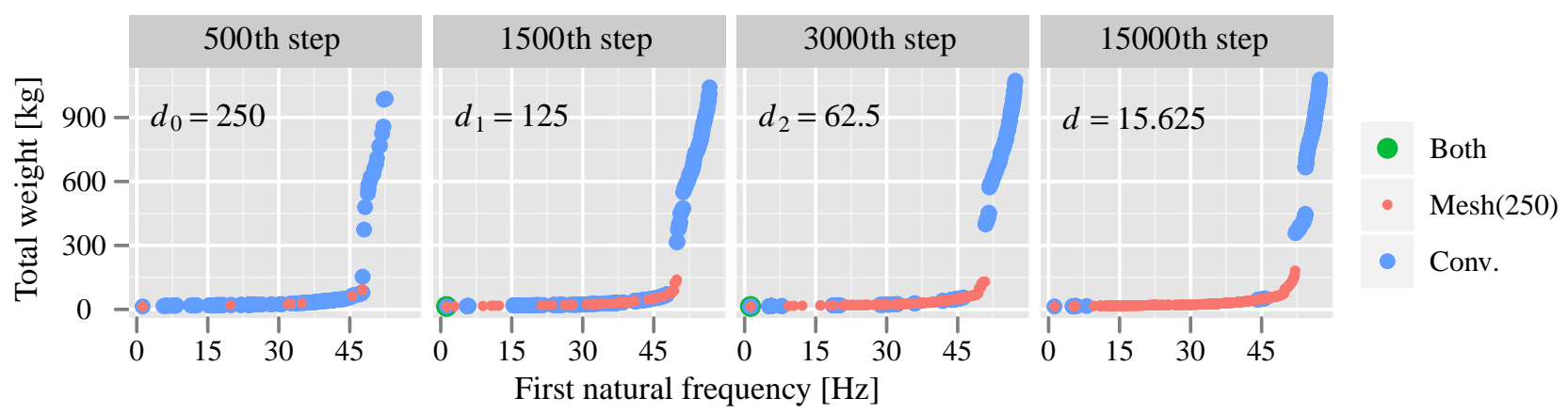

Fig. 15 Pareto optimal solutions in each step

来法の結果を見ると，500 ステップから 1500 ステップまではチャンピオンデータが大きく改善しているが， 1500 ステップ以降ではチャンピオンデータの変化があまり見られなくなっている .これに対して, $\operatorname{Mesh}(250)$ の結果で は，500 ステップでは従来法に比べてあまり良好なチャンピオンデータが得られていないものの，1500 ステップ では従来法と同程度のチャンピオンデータが得られており，3000 ステップでは従来法よりも優れたチャンピオン データが得られていることがわかる．

次に，Mesh(250) と従来法による試行計算で得られたすべてのチャンピオンデータから，ステップ毎にパレート 最適フロントを求めた . 図 15 は, 500 ステップ, 1500 ステップ, 3000 ステップ , 15000 ステップの 4 つの点にお けるパレート最適フロントである.ここに, 図中の緑色の点は両手法ともに求められたパレート最適解を, 青色 の点は従来法でのみ求められたパレート最適解を, 橙色の点はメッシュサイズ変更法でのみ求められたパレート 最適解を意味する . まず, 500 ステップの結果では, 従来法だけで求められた最適解の領域が広くなっている.し かし，1500 ステップや 3000 ステップの結果を見ると，メッシュサイズ変更法だけで求められた最適解がだんだん と増えており，15000 ステップまでには，質量が $200 \mathrm{~kg}$ 以下の領域のほとんどの最適解がメッシュサイズ変更法 によって求められている .このように , メッシュサイズ変更法によれば最小メッシュサイズに到達するよりも早い 段階で従来法よりも優れたパレート最適フロントが求められていることがわかる.一方，200 kg 以上の領域にあ る最適解 $\left(G_{14}, G_{15}, G_{16}, G_{17}\right.$ の位相を持った最適解) については, メッシュサイズ変更法では 15000 ステップ以降 の計算でも求めることはできなかった .ただし, 弚れらの最適解は, 表 2 から分かるように従来法でも 10 回の試 行計算のうち 1 回程度しか求めることができていない . このことから , この問題は両手法に共通する SA/GA ハイ ブリッド最適化手法の計算アルゴリズムに起因している可能性があると考えられる． 


\section{$5 \cdot 2$ Model 2 の計算結果}

次に, Model 1 よりも設計変数が多い Model 2 を対象として前節と同樣の検討を行った . 計算条件については Model 1 と全て同じである. 各手法の試行計算で得られた全てのチャンピオンデータを統合してパレート最適フロ ントを求めたところ，図 16 に示すような 23 種類の位相を持ったパレート最適解が得られた . また，各手法の試 行計算で得られたチャンピオンデータを比較したところ，Model 1 の結果と同樣にチャンピオンデータのランクや 位相の種類に関して手法毎の結果にばらつきがみられた . 乥こで, 5.1 .2 項と同樣に 4 種類の評価指標を用いて従 来法とメッシュサイズ変更法の計算性能の比較を行った .

図 17 は，手法毎に 4 種類の評価指標を世代毎に求めた結果である. 図の表示方法は図 11 と同樣である.まず， $N_{\text {all }}$ に関する結果を見ると，初期の世代では従来法の方が大きいものの，世代が進みメッシュサイズか変更され るにつれて ,メッシュサイズ変更法と従来法との差は小さくなっている．次に， $\bar{R}$ に関する結果を見ると，メッ シュサイズ変更法の方が従来法よりも小さくなっており，とくにMesh(125) と Mesh(250) の結果が良好である . 次 に， $N_{G}$ に関する結果を見ると，従来法の方がメッシュサイズ変更法よりもやや大きくなっている．しかしながら， $N_{\text {Gopt }}$ に関する結果を見ると, 両手法の值にあまり差が無いことから, メッシュサイズ変更法では, 従来法に比べ

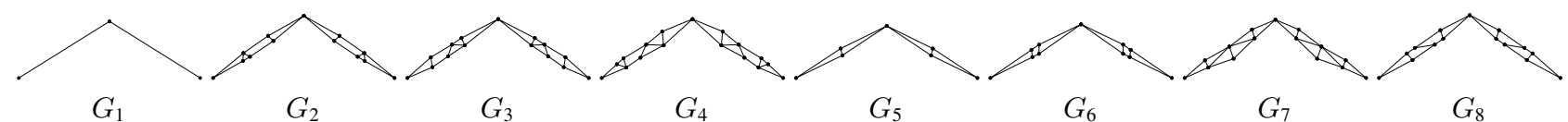

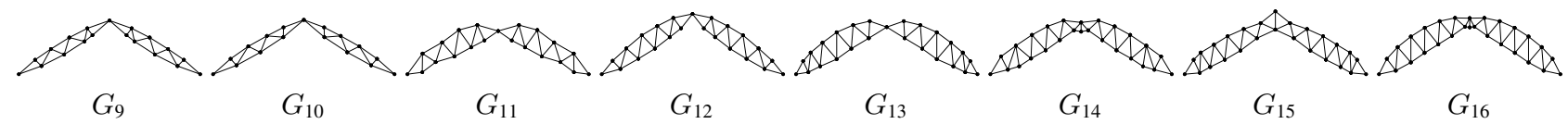

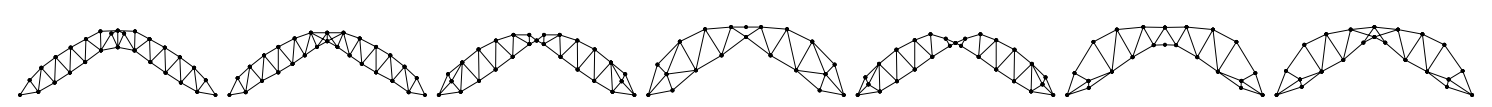$$
\begin{array}{lllllll}
G_{17} & G_{18} & G_{19} & G_{20} & G_{21} & G_{22} & G_{23}
\end{array}
$$

Fig. 16 Optimal topology of Model 2

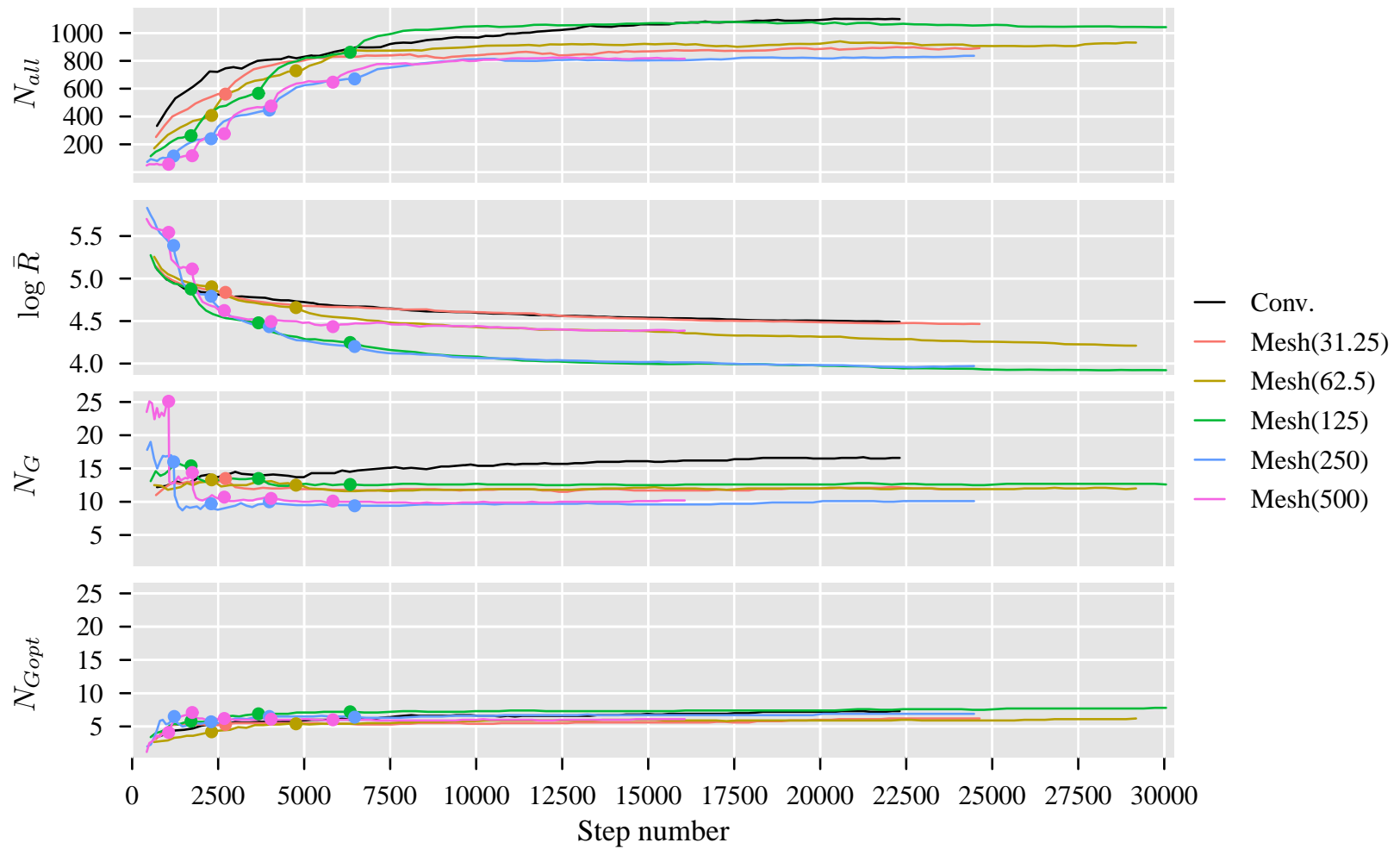

Fig. 17 Performance indicators of each method (Model 2) 
て発生した位相の多くがパレート最適フロントに含まれる位相であることがわかる .

以上のように , Model 2 に対する計算結果からもメッシュサイズ変更法の有効性を確認することができた .

\section{6.メッシュサイズ変更手続きの改良}

前章までの検討により，メッシュサイズ変更法では，従来法よりも効率的に優秀なチャンピオンデータが求めら れることが確認された . 本章では, メッシュサイズ変更法の更なる計算効率の向上を目指して計算手続きの改良 を行う.メッシュサイズ変更法では, $\hat{g}$ 世代毎にメッシュサイズが変更される .このため, チャンピオンデータが 早い世代で収束した場合でも， $\hat{g}$ 世代の計算が終了するまではメッシュサイズの変更が行われないので, 無䭾な計 算時間を要していると考えられる．乥こで本章では，前節で示した収束率を用いてメッシュサイズを変更する世 代を適切に設定する手続きを新たに導入する．

\section{1収束率を用いたメッシュサイズ変更世代の設定法}

新たに導入するメッシュサイズの変更世代の設定法は, 基本的にSA の終了判定方法 ${ }^{(5)}$ と同樣の概念を用いてい る.いま, 2 世代目以降の各世代に於いて収束率 $\varepsilon$ か観測されているとき, 直近の連続した $\tilde{g}$ 世代分の収束率 $\varepsilon$ に 対して, 帰無仮説を $H_{0}: \varepsilon=\hat{\varepsilon}$, 対立仮説を $H_{1}: \varepsilon<\hat{\varepsilon}$ とし, 有意水準 0.05 の下で角度変換を適用した $\arcsin (\sqrt{\varepsilon})$

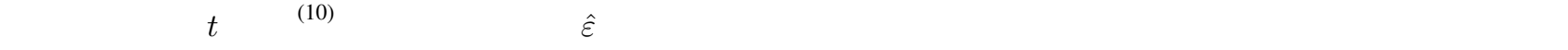
メッシュサイズを変更する .この方法によれば, 収束率が閾值 $\hat{\varepsilon}$ を回ったと推定される時点でメッシュサイズ を変更することができる．なお，本報では以降の計算において $\tilde{g} を 10$ としている．

\section{$6 \cdot 2$ 有効性の検討}

Model 1 を対象として, 収束率を用いたメッシュサイズ変更世代の設定法を導入したメッシュサイズ変更法 (以 下, 改良メッシュサイズ変更法と呼ぶ）により最適化計算を行った .ここでは, 500 世代までの計算に最も時間を 要した初期メッシュサイズ $125 \mathrm{~mm}$ の場合を例にとり，収束率の閾值を $\hat{\varepsilon}=0.6,0.7,0.8,0.9$ の 4 通りに設定した

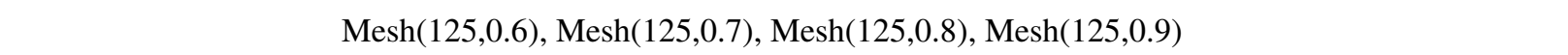

まず，各手法の試行計算で得られた計算結果に対して収束率を求めた . 図 18 は, 各手法の 10 回の試行計算毎 にメッシュサイズか変更された時の世代数およびステップ数を求め, その平均値と標準偏差をプロットした結果

である . 図中の横軸はステップ数，縦軸は世代数を表し，メッシュサイズが $125 \mathrm{~mm}$ から $62.5 \mathrm{~mm}$ に変更された

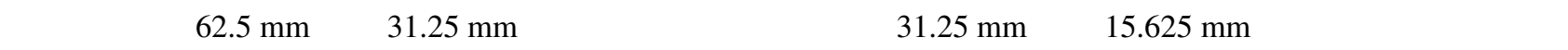
で示している．また，凡例に示す通り，線の色の違いが手法の違いを表している．なお，比較のため 5 章で用い たMesh(125)の結果も示している .この結果から，新しく改良メッシュサイズ変更法を導入したことにより，3回

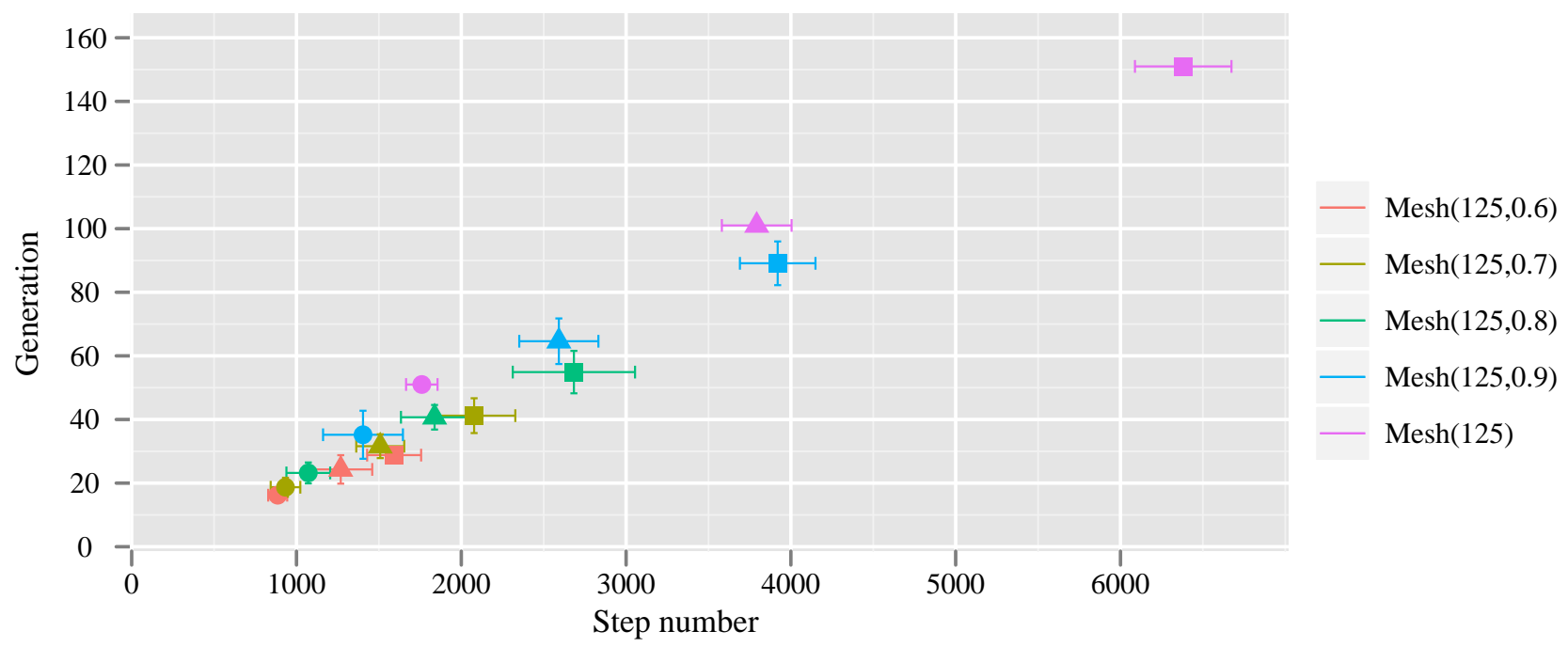

Fig. 18 Generation and step number when the procedure for changing mesh size was performed 
のメッシュサイズの変更がいずれも Mesh(125) よりも早い世代で行われていることがわかる . 各手法で最小メッ シュサイズに到達したステップ数の平均値は, Mesh(125) では 6381 ステップ, Mesh(125,0.9) では 3968 ステップ, $\operatorname{Mesh}(125,0.8)$ では 2652 ステップ, Mesh(125,0.7) では 2094 ステップ, Mesh(125,0.6) では 1522 ステップであり， 閾值 $\hat{\varepsilon}$ の值が小さいほど少ないステップ数で最小メッシュサイズに到達している.

次に，5.1.1 項で述べた 4 種類の評価指標を用いて各手法の計算性能の比較を行った . 図 19 は, 評価指標を世代 毎に求め，图 11 と同樣の表記方法により示した結果である．まず， $N_{\text {all }}$ に関する結果を見ると，改良メッシュサ イズ変更法では Mesh(125) と比較して少ないステップ数で多くのチャンピオンデータを求めることができている . また， $\bar{R}$ に関する結果を見ると，メッシュサイズの変更が行われる 5000 ステップまでの範囲では, 改良メッシュ サイズ変更法の $\log \bar{R}$ の值が Mesh(125) よりも小さくなっている.ただし , ステップ数が増加すると,$\hat{\varepsilon}$ の值が小 さいほど $\log \bar{R}$ の值が大きくなっている .これは, メッシュサイズの変更を早く行い過ぎると，優秀なチャンピオ ンデータが得られにくくなってしまうことを示唆している．したがって， $N_{G}$ および $N_{G o p t}$ の結果から，位相の種 類数に関しては各手法で大きな差違はないことを踏まえると, 改良メッシュサイズ変更法の中では, Mesh $(125,0.9)$ が最も良好な結果を得ていると言える .

図 20 は，800 ステップ，1500 ステップ，2000 ステップ, 3000 ステップ，10000 ステップの 5 つの点において， $\operatorname{Mesh}(125)$ とMesh(125,0.9) の手法により得られたパレート最適フロントの一部を目的関数空間上にプロットした 結果である. 図の表示方法は図 15 と同樣であり，緑色の点は両手法ともに求められたパレート最適解を，橙色は $\operatorname{Mesh}(125)$ でのみ求められたパレート最適解を, 青色は Mesh(125,0.9) でのみ求められたパレー最適解を示してい る .なお，図中には光れ光れのステップにおける各手法のメッシュサイズを示している．まず，800ステップで は，両手法ともまだ初期メッシュサイズ $d_{0}$ のままであり，この時点では両手法の結果に有意な差が見られない． 次に, 1500 ステップでは, Mesh(125,0.9) のメッシュサイズが $d_{1}$ に変更されており，パレート最適フロントには $\operatorname{Mesh}(125,0.9)$ で得られたパレート最適解が広く分布している .これは， 5 章で述べたように，Mesh(125,0.9) では メッシュサイズが変更されたことによってチャンピオンデータが大きく改善されたことによるものと考えられる． 次に, 2000 ステップでは, Mesh(125) のメッシュサイズが $d_{1}$ に変更され，パレート最適解の個数か増加している ただし，この段階においてもMesh(125,0.9) の方がパレート最適解を広く求めることができている.このような傾

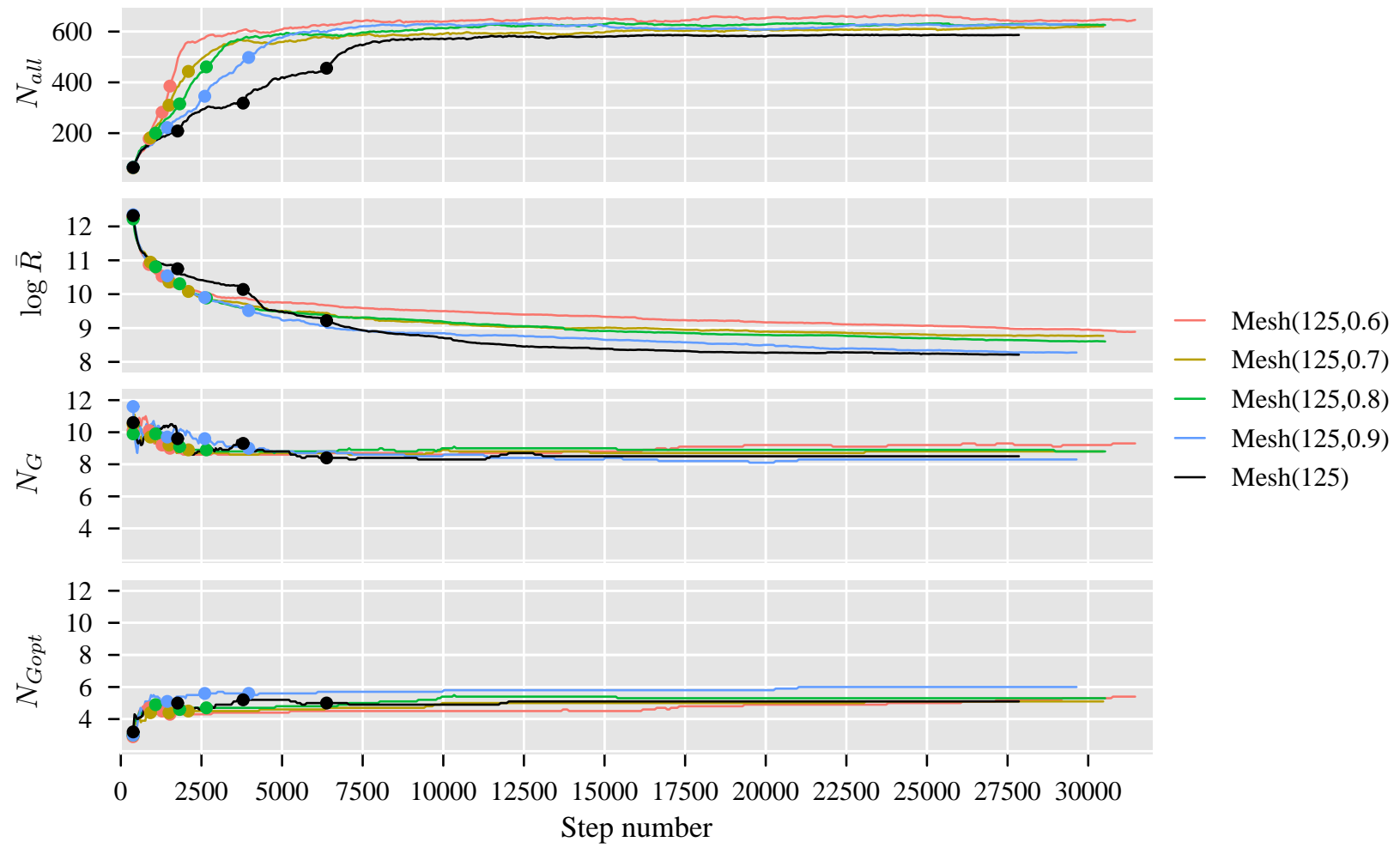

Fig. 19 Performance indicators of each method (Model 1) 


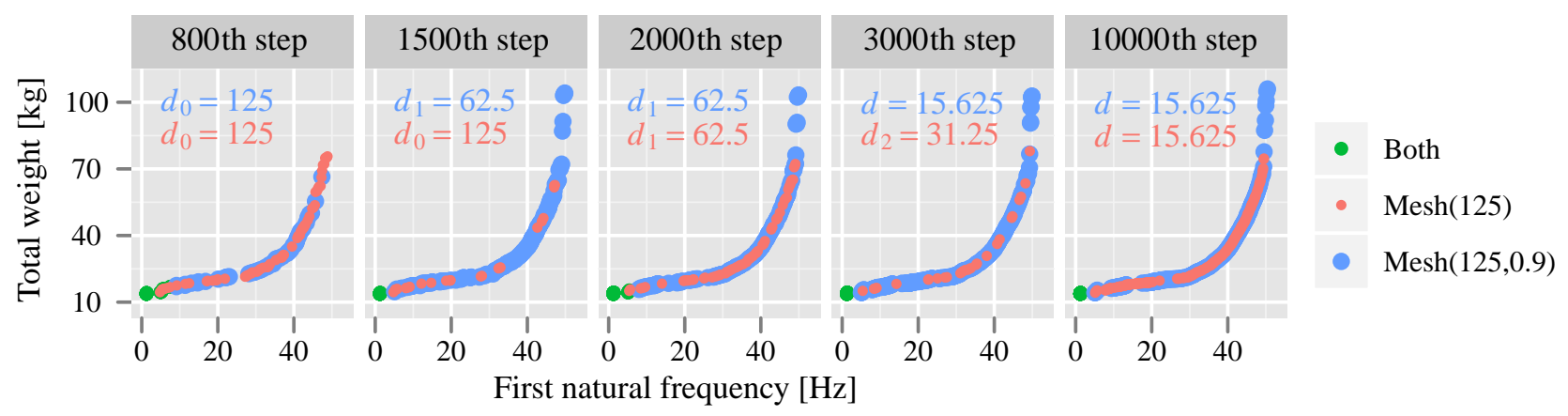

Fig. 20 Pareto optimal solutions in each step

向は 3000 ステップや 10000 ステップにおいても確認することができる .

以上の結果から，改良メッシュサイズ変更法では, 早い段階でメッシュサイズの変更を行うことによって, 少な いステップ数で優秀なチャンピオンデータが求められることが確認された .ただし，弚のためには閾值 $\hat{\varepsilon}$ を適切 に設定する必要があるようである . $\hat{\varepsilon}$ の設定方法の具体的な検討については今後の課題としたい .

\section{7. 結言}

SA/GA ハイブリッド最適化手法の更なる性能向上を目指して，SA/GA ハイブリッド最適化手法にメッシュサイ ズ変更法を導入することを試みた. 弚の適用例として, 2 次元骨組構造物の位相・形状同時多目的最適化問題を対 象として計算アルゴリズムの定式化を行うとともに，具体的な数值計算結果に基づいて 4 種類の評価指標を用い て本手法の有効性について検証した . 兴の結果 , メッシュサイズ変更法を導入した本手法によれば , 従来法と同 程度の位相の種類数を維持しつつ, 従来法よりもランクの高いチャンピオンデータが数多く求められることが確 認された .メッシュサイズ変更法では, 初期メッシュサイズを適切に設定することにより, 計算過程の各段階にお いて生成可能な探索個体の数が少なく抑えられる．これにより，計算の初期段階では従来法よりも解が劣化する ものの, メッシュサイズが変更される度にチャンピオンデータの個数やランクが大きく改善され, 結果として従 来法よりも早い段階で良好なチャンピオンデータを得ることが可能となる.さらに , 収束率を用いてメッシュサ イズを変更する世代を適切に決めることによって，計算効率の更なる向上が可能であることが確認された .

\section{文献}

(1) Sadiq M. Sait and Habib Youssef, "Iterative Computer Algorithms with Applications in Engineering: Solving Combinatorial Optimization Problems", (2000), IEEE Computer Society.

(2) Deb, K., Pratap, A., Agarwal, S. and Meyarivan, T.," A Fast and Elitist Multiobjective Genetic Algorithm : NSGA-II ” , IEEE Transactions on Evolutionary Computation, Vol.6, No.2, (2002), pp.182-197.

(3) Kirkpatrick, S., Gelatt Jr., C.D., Vecchi, M.P.,“ Optimization by simulated annealimg” , Science, Vol.220, No.4598, (1983), pp.671-680.

(4) Sakamoto, Y., Bonkobara, Y., Kondou, T. and Kuroki, H.,“ Simultaneous Optimization for Topology and Geometry of Framed Structure Using Hybrid Optimization Method” , Proc. Of 13th Asia Pacific Vibration Conference 2009, CD-ROM, No.76, (2009).

(5) 坂本裕一郎, 盆子原康博, 近藤孝広“, SA/GA ハイブリッド最適化手法を用いた 2 次元骨組構造物の位相・形状同時多目 的最適化”，日本機械学会論文集 C 編, Vol.77, No.781，(2011)，pp.3454-3468.

(6) 田川浩, 大崎純 “ 一樣部材断面積を有する平面卜ラスのトポロジー・節点位置同時最適化”, 日本建築学会構造系論文 集, No.521, (1999), pp.73-80 .

(7) Fonseca, C.M. and Fleming, P.J.," Genetic Algorithms for Multiobjective Optimization: Formulation, Discussion and Generalization ”, Proceedings of the Fifth International Conference on Genetic Algorithms, (1993), pp.416-423.

（8）盆子原康博，近藤孝広，綾部隆，崔銘秀“" グラフ理論を利用した一般化伝達岡性係数法の提案”，日本機械学会論文集 C 編，Vol.71，No.712，(2005)，pp.3343-3350.

（9）廣安知之, 三木光範，渡邊真也，畠中一幸 “多目的分散遺伝的アルゴリズムにおけるシェアリング, 収束判定, 及び解の 評価手法の検討”, 同志社大学理工学研究報告, Vol.40, No.4 , (2000), pp.189-200.

(10) 武藤眞介, 統計解析ハンドブック, (1995), 朝倉書店 . 